Conorly Noryan, F.R.C.S.I., read a paper on "Iarvated Insanity," giving the history of two men who had, through life, shown at times well-marked delnsions, but whose insanity had not been brought to light during their period of service in the army and police, though both were constantly in the possession of arms.

Dr. Duncan asked was there any history of masturbation in these cases?

Dr. DrAPER asked were these to be looked on as distinct types of insanity ? That the fashion now-a-days seemed to be to divide insanity into different species, whereas he agreed with Dr. Sankey that insanity was only one disease, and that many persons walking about might be said to be types of larvated insanity. He instanced the case of a gentleman who, on the death of his first wife, almost became insane from grief, but in six months married again, at the same time insisting on decorating his first wife's grave with wreaths.

Dr. Norma replied that he used the word "larvated " only to describe the course of the disease. In one of his cases distinct delusious had been shown for twenty-five years, during which time the man had continned in the public service with arms in his hands. In the second case the man had taken to the profession of arms under distinct delusions, which had never been discovered, though there were no lucid intervals. His delusions, which were always of an exalted type, had continued from his youth.

Dr. MolONEY read a short paper on two cases of insanity from masturbation.

\title{
GUILD OF FRIENDS OF THE INFIRM OF MIND.
}

We have been requested to bring this Society, instituted in 1871, under the notice of our readers. The President is the Bishop of London, and the Secretary the Rev. H. Hawkins, the chaplain of the Colney Hatch Asylum, who will be glad to furnish particulars to any one desiring them. No further payment is required than a contribution of 18., payable on membership, which will only be granted to those strictly in communion with the Church of England, and who are willing to promote the objects of the Association by prayer and help. 'I'be day of commemoration is the festival of S. Lake.

The objects of this Association, which takes for its text, " $\mathrm{He}$ shall be for a sanctnary," are stated to be as follows :-

1. Intercessory prayer.

2. Visits to friendless patients in asylums, in conformity with the regulations of the establishment.

3. Correspondence by post.

4. Seeking situations for convalescents.

5. Promoting Convalescent Homes for temporary rest after mental illness.

6. Maintaining friendly intercourse with discharged patients.

7. Recommending efficient attendants.

8. Furthering, in any other way, the interests of the infirm in mind.

The number of past and present associates is about 200 .

1. Intercessions of many have been offered on behalf of the objects of the Association.

N.B.-A special "Union for Prayer for the Infirm in Mind" has been formed. This might suit the case of those who could not otherwise assist. "You that can be no other way useful, yet you shall be no small belpers, if you be much in prayer."-Lrightor.

2. Personal visits have been paid to many patients : nearly forty associates 
-some long-tried friends-have shown kindness in this manner. Kind gifts have been brought, invitations to tea given, \&c., and many tokens of sympathy evinced.

3. Postal communications have been very numerous and varied. Letters, books, magazines, pictnres, Christmas, Easter, and other cards, almanacks, flowers, postage stamps, \&c., have been forwarded, and given much pleasure.

\section{POSTSCRIPT ON THE LUNACY BILL.}

Since the observations on the Bill in the "Notes of the Quarter" were written, the representations made by the Parliamentary Committee of the Association and other bodies to the Lord Chancellor on the very unfair and injurious clauses it contains have had a favourable effect, and his Lordship, on the Bill going into Committee on March 18th, introduced certain valuable amend. ments and promised others, which materially modify the clauses referred to. A communication was made to Lord Esher, in which stress was land upon the necessity of still further protecting medical men by the introduction of a clause requiring the sanction of a judicial functionary before a civil action can be brought against medical men, and the granting of power to the defendant in a threatened lunacy action to require the plaintiff to give secarity for costs.

It may be observed that there was a marked improvement in the general tone of the debate in the House of Lords on going into Committee in the references made to the branch of the medical profession practising in lunacy.

Putting aside minor points upon which the Association has made suggestions, the main proposals and protests have reference to :-

1. More complete protection of medical men signing certificates, and of private persons and institutions receiving patients.

2. Prevention of frivolous actions brought by discharged lunatics by requiring security for costs.

3. Prevention of the confiscation of the vested interests of the proprietors of private asylums.

4. Single patients.

5. Examination of alleged lunatic by medical men, and not the magistrate, in cases in which the latter defers the granting of an order for admission into an asylum for the purpose of a further examination.

The Chairman of the Committee, Dr. Rayner, writes :-

The following suggestions (many of which have been adopted) were forwarded to the Lord Chancellor prior to the second reading of the Act, and in a second communication to his Lordship the Committee expressed the opinion that Clause 43 " was a veiled confiscation of the vested interests of the private asylum proprietors," and that Clause 26, s.8. 1, by compelling every person suffering from mental disorder requiring treatment away from home to be "incarcerated" in a public asylum and branded by legal process as a lunatic would inflict grievous harm and much social suffering in many cases of acute and transient insanity. This was exemplified by cases of puerperal mental disorder. To each communication his Lordship returned a courteous reply, promising attention to the suggestions and criticisms forwarded. 